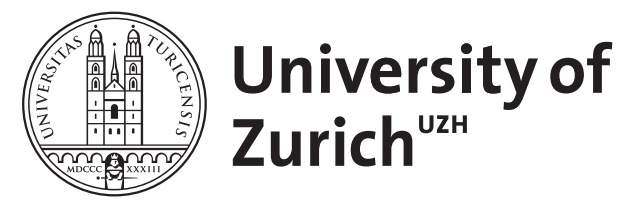

\title{
Plato as Teacher of Socrates?
}

\author{
Ferber, Rafael
}

\begin{abstract}
What distinguishes the Platonic Socrates of the early from the Platonic Socrates of the middle Platonic dialogues? According to a well-known opinion, the "dividing line" lies in the difference between the Socratic and the Platonic theory of action. Whereas for the Platonic Socrates of the early dialogues, all desires are good-dependent, for the Platonic Socrates of the middle dialogues, there are good-independent desires. The paper argues first (I), that this "dividing line" is blurred in the "Symposium" and second (II), that we have in the "Symposium" a more distinctive dividing line, namely the introduction of the separate existence of the idea of beauty. This introduction of separate ideas and the lack of (noetic) understanding of separate ideas - here the idea of beauty - may indicate the limit not only of the Platonic Socrates of the early Platonic dialogues, but of the historical Socrates as well.
\end{abstract}

Posted at the Zurich Open Repository and Archive, University of Zurich

ZORA URL: https://doi.org/10.5167/uzh-124688

Book Section

Published Version

Originally published at:

Ferber, Rafael (2016). Plato as Teacher of Socrates? In: Tulli, Mauro; Erler, Michael. Plato in Symposium : Selected Papers from the tenth Symposium Platonicum. St. Augustin: Academia Verlag, 443-448. 
Mauro Tulli / Michael Erler (eds.)

Plato in Symposium 


\title{
International Plato Studies \\ Published under the auspices of the \\ International Plato Society
}

\author{
Series Editors: \\ Franco Ferrari (Salerno), Lesley Brown (Oxford), \\ Marcelo Boeri (Santiago de Chile), Filip Karfik (Fribourg), \\ Dimitri El Murr (Paris)
}

Volume 35 


\title{
PLATO IN SYMPOSIUM
}

\author{
SELECTED PAPERS FROM THE \\ TENTH SYMPOSIUM PLATONICUM
}

Edited by

MAuro Tulli AND MiCHAEL ERLER

Academia Verlag $M$ Sankt Augustin 
Illustration on the cover by courtesy of the Bodleian Library,

Oxford, MS. Ashmole 304, fol. $31 \mathrm{v}$.

Bibliografische Information der Deutschen Nationalbibliothek

Die Deutsche Nationalbibliothek verzeichnet diese Publikation in der

Deutschen Nationalbibliografie; detaillierte bibliografische Daten sind im Internet über http://dnb.ddb.de abrufbar.

ISBN: 978-3-89665-678-0

1. Auflage 2016

(C) Academia Verlag

Bahnstraße 7, D-53757 Sankt Augustin

Internet: www.academia-verlag.de

E-Mail: info@academia-verlag.de

Printed in Germany

Alle Rechte vorbehalten

Ohne schriftliche Genehmigung des Verlages ist es nicht gestattet, das Werk unter Verwendung mechanischer, elektronischer und anderer Systeme in

irgendeiner Weise zu verarbeiten und zu verbreiten. Insbesondere vorbehalten sind die Rechte der Vervielfältigung - auch von Teilen des Werkes -

auf fotomechanischem oder ähnlichem Wege, der tontechnischen Wiedergabe, des Vortrags, der Funk- und Fernsehsendung, der Speicherung in Datenverarbeitungsanlagen, der Übersetzung und der literarischen und anderweitigen Bearbeitung. 


\section{List of contributors}

Olga Alieva, National Research University Higher School of Economics, Moscow Carolina Araújo, Universidade Federal do Rio de Janeiro

Francesco Aronadio, Università di Roma Tor Vergata

Ruby Blondell, University of Washington

Sandra Boehringer, Université de Strasbourg

Marcelo D. Boeri, Universidad Alberto Hurtado, Chile

Beatriz Bossi, Universidad Complutense de Madrid

Francisco Bravo, Universidad Central de Venezuela

Luc Brisson, CNRS, Villejuif

Giuseppe Cambiano, Scuola Normale Superiore, Pisa

Andrea Capra, Università degli Studi di Milano

Giovanni Casertano, Università degli Studi di Napoli "Federico II"

Gabriele Cornelli, Universidade de Brasília

Michele Corradi, Aix-Marseille Université

Ivana Costa, Universidad de Buenos Aires

Gabriel Danzig, Bar-Ilan University

Piera De Piano, Università degli Studi di Napoli "Federico II"

Dino De Sanctis, Università di Pisa

Margherita Erbì, Università di Pisa

Mehmet M. Erginel, Eastern Mediterranean University

Rafael Ferber, Universität Luzern / Universität Zürich

Arianna Fermani, Università di Macerata

Giovanni R.F. Ferrari, University of California, Berkeley

Lloyd P. Gerson, University of Toronto

Christopher Gill, University of Exeter

Stephen Halliwell, University of St Andrews

Edward C. Halper, University of Georgia

Annie Hourcade Sciou, Université de Rouen

Chad Jorgenson, Université de Fribourg

Yahei Kanayama, Nagoya University

Filip Karfik, Université de Fribourg

Christian Keime, Université Paris IV-Sorbonne / University of Cambridge

Manfred Kraus, Eberhard-Karls-Universität Tübingen

Yuji Kurihara, Tokyo Gakugei University

Annie Larivée, Carleton University

Aikaterini Lefka, Université de Liège

Francisco L. Lisi, Instituto Lucio Anneo Séneca / Universidad Carlos III de Madrid Arnaud Macé, Université de Franche-Comté

Graciela E. Marcos de Pinotti, Universidad de Buenos Aires - CONICET

Silvio Marino, Università degli Studi di Napoli "Federico II"

Giusy Maria Margagliotta, Albert-Ludwigs-Universität Freiburg

Irmgard Männlein-Robert, Eberhard-Karls-Universität Tübingen 
Mariella Menchelli, Università di Pisa

Maurizio Migliori, Università di Macerata

Gerard Naddaf, York University

Hugues-Olivier Ney, Aix-Marseille Université

Noburu Notomi, Keio University, Tokyo

Lidia Palumbo, Università degli Studi di Napoli "Federico II"

Richard D. Parry, Agnes Scott College

Richard Patterson, Emory University

Federico M. Petrucci, Scuola Normale Superiore / Università di Pisa

Mario Regali, Università degli Studi di Bari "Aldo Moro"

Olivier Renaut, Université Paris Ouest - Nanterre La Défense

Nicholas P. Riegel, University of Toronto

Cristina Rossitto, Università di Padova

Christopher Rowe, Durham University

David T. Runia, Queen's College, The University of Melbourne

$\dagger$ Samuel Scolnicov, The Hebrew University of Jerusalem

Richard Stalley, University of Glasgow

Alessandro Stavru, Freie Universität Berlin

Thomas Alexander Szlezák, Eberhard-Karls-Universität Tübingen

Ikko Tanaka, Kyoto University

Harold Tarrant, University of Newcastle, Australia

Alonso Tordesillas, Aix-Marseille Université

Álvaro Vallejo Campos, Universidad de Granada

Mario Vegetti, Università degli Studi di Pavia

Matthew D. Walker, Yale-NUS College

Roslyn Weiss, Lehigh University 


\section{Table of Contents}

List of contributors

Table of contents

Preface (Mauro Tulli)

vii

vil

I C.J. De Vogel Lecture

Stephen Halliwell

Eros and Life-Values in Plato’s Symposium

\section{Reading the Symposium}

Francisco Bravo

Luc Brisson

¿Propone el Banquete una ciencia del amor?

Éros éducateur: entre paiderastia et philosophia

Gabriel Danzig

"Testing the Truth and Ourselves" (Prot. 348a).

Arianna Fermani

Boasting and Philosophizing in Plato's Symposium

Perché tanta "morte" in un dialogo sull'amore e sulla

vita? Riflessioni sulla dialettica amore-morte-immortalità nel Simposio di Platone

Christian Keime

Lector in dialogo: Implied Readers and Interpretive

Strategies in Plato's Symposium ................................... 52

Mariella Menchelli

Isocrate, la condotta di vita e il discorso di Diotima nel

Simposio di Platone

Maurizio Migliori

Hugues-Olivier Ney

Nicholas P. Riegel

L'importanza della dimensione esperienziale ed empirica

nel Simposio ............................................................. 65

L'amour, drame de Socrate ........................................... 71

Tragedy and Comedy at Agathon's Party:

Two Tetralogies in Plato's Symposium ............................ 77

Harold Tarrant

Stylistic Difference in the Speeches of the Symposium ....

\section{The Frame Dialogue}

Dino De Sanctis

Agathon agathos:

l'eco dell'epos nell'incipit del Simposio ........................... 92

Giovanni R.F. Ferrari

Lidia Palumbo

No Invitation Required? A Theme in Plato's Symposium 98

Narrazioni e narratori nel Simposio di Platone ................ 104

Matthew D. Walker

The Functions of Apollodorus

\section{Phaedrus}

Annie Hourcade Sciou

Éros sans expédient: Platon, Banquet, 179b4-180b5

Noburu Notomi

Phaedrus and the Sophistic Competition of Beautiful

Speech in Plato's Symposium

\section{Pausanias}

Olga Alieva

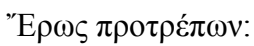

Philosophy and Seduction in the Symposium 
Olivier Renaut

\section{Eryximachus}

Ivana Costa

Silvio Marino

Richard D. Parry

Richard Stalley

\section{Aristophanes}

Michele Corradi

$\uparrow$ Samuel Scolnicov

Roslyn Weiss

\section{Agathon}

Aikaterini Lefka Irmgard Männlein-Robert

Mario Regali

Richard Patterson

\section{Diotima}

Francesco Aronadio

Giovanni Casertano Mehmet M. Erginel Lloyd P. Gerson

Chad Jorgenson

Yahei Kanayama

Filip Karfík

Manfred Kraus

Yuji Kurihara

Francisco L. Lisi

Arnaud Macé

Giusy Maria Margagliotta
La pédérastie selon Pausanias:

un défi pour l'éducation platonicienne 140

Qué aporta Erixímaco a la filosofía del Simposio y a

Platón

La medicina di Erissimaco: appunti per una cosmologia

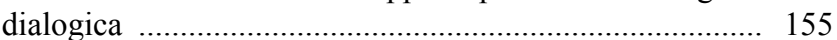

Eryximachus' Physical Theory in Plato's Symposium ...... 160

Sophrosyne in the Symposium ...................................... 165

Aristofane e l'ombra di Protagora: origini dell'umanità e orthoepeia nel mito degli uomini-palla 172

What Socrates Learned from Aristophanes

(and What He Left Behind)

Split Personalities in the Symposium and the Bible:

Aristophanes' Speech and the Myth of Adam and Eve

Eros Soter. How Can Love Save Us?

Die Poetik des Philosophen:

Sokrates und die Rede des Agathon

La mimesis di sé nel discorso di Agatone:

l'agone fra poesia e filosofia nel Simposio ....................... 204

Agathon's Gorgianic Logic

What's in the Name "Eros"?

Onoma and Holon in Symposium 204e-206a .................. 218

La difficile analogia tra poesia e amore .......................... 224

Plato on the Pangs of Love ........................................... 231

The Hermeneutics of Mystery in Plato's Symposium ....... 237

Becoming Immortal in the Symposium and the Timaeus .. 243

Recollecting, Retelling and Melete in Plato's Symposium:

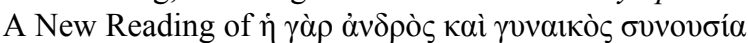

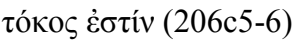

Eros und Unsterblichkeit:

das Hervorbringen im Schönen

Socrates' thea:

The Description of Beauty in Symposium 211a and the

Parmenidean Predicates of Being

Telos and Philosophical Knowledge in Plato's Sympo-

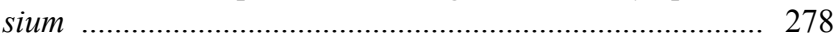

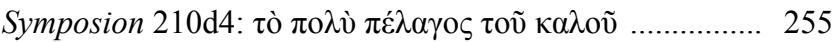

L'océan du beau:

la Forme et ses reflets hétérogènes (Banquet, 210a-211c) 291

Eros e l'Anima nel Simposio 
Cristina Rossitto

Ikko Tanaka

Alonso Tordesillas

Mario Vegetti

X Alcibiades

Gabriele Cornelli

Edward C. Halper

Alessandro Stavru

\section{The Ethics of Eros}

Carolina Araújo

Marcelo D. Boeri

Christopher Gill

Annie Larivée

Federico M. Petrucci

Christopher Rowe

David T. Runia

Álvaro Vallejo Campos

\section{The Picture of Socrates}

Beatriz Bossi

Giuseppe Cambiano

Andrea Capra

Rafael Ferber

Graciela E. Marcos de Pinotti

Gerard Naddaf

Thomas Alexander Szlezák

\section{Reception}

Ruby Blondell and Sandra Boehringer
Plato's Symposium and the Notion of Intermediate 303

Divine Immortality and Mortal Immortality in Plato's

Symposium

Le beau, une nature merveilleuse, une vision soudaine

(Banquet 210e2-211d1)

Immortalità personale senza anima immortale:

Diotima e Aristotele

Alcibiades' Connection: Plato's Symposium Rewriting the Case on Socrates and Alcibiades

Alcibiades' Refutation of Socrates

Socrate karterikos (Platone, Simposio 216c-221b)

Who Loves?

The Question of Agency in Plato's Symposium ................ 356

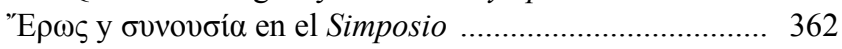

Are the "Higher Mysteries" of Platonic Love Reserved

for Ethical-Educational Pederasty?

Le pouvoir protreptique de l'amour.

Eros, soin de soi et identité personnelle dans le Banquet . 380

La dottrina della virtù di secondo grado nel Simposio ...... 386

On the Good, Beauty, and the Beast in Plato's Sympo-

sium

Eudaimonist Closure in the Speeches of Plato's Sympo-

sium

Desire and Will in the Symposium

On Which Step of the Scala Amoris Is Socrates Standing in the Dramatic Action of the Symposium?

Notes on the Practical Consequences of Theory .............. 420

Chi è il Socrate del Simposio? ......................................... 428

Transcoding the Silenus. Aristophanes, Plato and the

Invention of Socratic Iconography …............................ 437

Plato as Teacher of Socrates? ......................................... 443

Sócrates aprendiz y maestro de Eros .............................. 449

The Young "Historical" Socrates

in the Apology and Symposium ....................................... 455

Sokrates' Rollen im Symposion.

Sein Wissen und sein Nichtwissen

Un Banquet revisité:

l'érotisme paradoxal de Platon et de Lucien 470 
Piera De Piano

Margherita Erbì

\section{Indices}

Index locorum

Index nominum
Gli eroi e la natura demonica di Amore:

Proclo interprete di Simposio 201e-204b 476

Lettori antichi di Platone:

il caso del Simposio (POxy 843) 


\title{
Plato as Teacher of Socrates?
}

\author{
Rafael Ferber \\ Universität Luzern / Universität Zürich
}

That the historical Socrates did exist is a fact beyond reasonable doubt. ${ }^{1}$ It is also a fact that Plato made him the protagonist of his early and middle dialogues, including the Symposium. Although Socrates as protagonist has been replaced in the later dialogues by the Eleatic Stranger, Timaeus and the Athenian, even the latter two remain Socratics in at least one important point. Both defend again the paradox that nobody does wrong willingly (cf. Tim. 86d7-e3; Leg. V 731c3-5, IX 860d1-2). If we assume that Plato expresses with the voices of Timaeus and the Athenian some of his own views, we may also assume that Plato, too, remains a Socratic (at least in this sense) throughout his life. In the following, I concentrate on the Platonic Socrates without discussing the philosophy of the historical Socrates - with the exception of a guess at the end.

I therefore do not enter into the question of what distinguishes the historical Socrates from the Platonic one, but what distinguishes the Socrates of the early from the Socrates of the middle dialogues. According to a well-known opinion, the "dividing line" lies in the difference between the Socratic and the Platonic theory of action. Whereas for the Platonic Socrates of the early dialogues all desires are good-dependent, for the Platonic Socrates of the middle dialogues there are good-independent desires. I argue first (I) that this "dividing line" is blurred in the Symposium, and second (II) that we have in the Symposium a more distinctive dividing line, namely the introduction of the separate existence of the idea of beauty.

\section{I.}

Socrates $-[\ldots]-$ is fundamentally at odds with Plato on the implications of only one question: a question about psychology of action. This is the question whether it is possible for any actions in that standard group of actions which Aristotle would later call 'voluntary actions' to be the direct result merely of irrational desires taken together with certain beliefs. ${ }^{2}$

Under irrational desires, the authors of this statement $-\mathrm{T}$. Penner and $\mathrm{Ch}$. Rowe - seem to understand blind desires based on "physiological needs". ${ }^{3}$ Terminologically we may call these irrational - or subrational - desires "sensations" in distinction from "emotions". Whereas sensations are not directed at intentional objects and are not dependent on some cognition of the good, emotions are directed at and depend on some cognition of the good. Sensations such as hunger or thirst, as simple raw experiences, have not yet fastened on any "objects" in the world. But they also include a degree of conscious experience and qualitative but not yet representational content. In distinction, emotions - such as anger (thymos), pleasure (hedone), grief (lype), love (eros) and fear (phobos) (cf. Prot. 352b7-8) - include repre-

${ }^{1}$ Cf. Kleve (1987).

2 Penner \& Rowe (2005), 295.

${ }^{3}$ Rowe (2005), 216. 
sentational and cognitive content. In fact, the Socrates of the Apology makes it sound as if fear is just a cognitive condition: "To fear death, gentlemen, is no other than to think oneself wise when one is not, to think one knows what one does not know" (Apol. 29a5-b1, transl. Grube). To use stoic terminology, sensations are pre-emotions or propatheiai, whereas emotions are pathe based on judgments. ${ }^{4}$

So formulated, the thesis would be that Plato introduced with the epithymetikon of his tripartite model of the soul sensations or propatheiai. The epithymetikon would then be a preemotion or propatheia. Although the doctrine of the tripartite soul may be traced back to the Apology (29d8) and the Gorgias (493a3-4), ${ }^{5}$ we find the explicit argument for it only in the Republic (cf. 435e-442a). ${ }^{6}$ Nevertheless, the tripartite soul may also be implied in the Symposium when Diotima distinguishes between love for money-making (chrematismon), love for sport (philogymnastia) and love for wisdom (philosophia) (Symp. 205d4-5)7 and between different kinds of immortality: biological, which corresponds to the epithymetikon, and meritorious (Symp. 208d-210a), which corresponds to the thymoeides. ${ }^{8}$ Eros is a kind of epithymia (cf. Symp. 200a2-3) ${ }^{9}$ and seems to be itself tripartite, so that each part of the tripartite soul has its own eros, the epithymetikon, e.g. for money, the thymoeides for social recognition and the logistikon for wisdom.

This tripartite model of the soul has been treated in Plato scholarship separately from other models of the soul. But we gain additional intelligibility of this model if we supplement it with the tripartite model introduced by Descartes and repeated by F. Brentano. Descartes distinguishes (a) ideas (in his sense), ${ }^{10}$ (b) judgments and (c) acts of will, ${ }^{11}$ and Brentano distinguishes (a) representations, (b) judgments and (c) acts of will, which he also calls motions of the soul, interests, or acts of love and hate. ${ }^{12}$ This model may go back to Aristotle, insofar as right desire (orexis orthe) presupposes true thinking or judgment (logos alethes) (cf. EN VI 2,1139a21-26) and thinking images (phantasmata) (cf. An. III 7, 431a14-16). Because "acts of will" in the broad sense of desires (epithymiai) are based on a belief, it partially even goes back to the early dialogues of Plato (cf. Prot. 358c6-d2, Gorg. 468b1-2). According to this model, consciousness has different levels. The lowest is that of (a) ideas or representations, the second of (b) judgments and the third of (c) acts of will. Judgments require ideas or representations; acts of will require both judgments and representations. Without representations, I cannot regard anything as either true or false, or desire anything as good or bad. Likewise, without judgment, that is, without evaluating something as good or bad, I cannot desire

\footnotetext{
$4 \mathrm{Cf}$. for this distinction, e.g., Seneca, De ira II 2: [...] Omnes enim motus qui non uoluntate nostra fiunt inuicti et ineuitabiles sunt, ut horror frigida adspersis, ad quosdam tactus aspernatio; ad peiores nuntios surriguntur pili et rubor ad inproba uerba suffunditur sequiturque uertigo praerupta cernentis: quorum quia nihil in nostra potestate est, nulla quominus fiant ratio persuadet. Ira praeceptis fugatur; est enim uoluntarium animi uitium, non ex his quae condicione quadam humanae sortis eueniunt ideoque etiam sapientissimis accidunt, inter quae et primus ille ictus animi ponendus est qui nos post opinionem iniuriae mouet. I owe the reference to stoic terminology to Anthony Price.

5 Cf. Burnet (1924), ad 29d8: "This enumeration [sophia, ischys, chremata] implies the doctrine of the 'tripartite soul'; for it gives the objects of to epithymetikon, to thymoeides, and to logistikon'. Slings (1994), 137 n. 33: "tês [...] psychês touto en hôi epithumiai eisi. This implies the existence of to epithymetikon; it certainly is much more definitive than the popular distinction between 'reason and impulse' [Dodds ad loc.]"'.

6 Cf. Ferber (2013), 233-236, with further literature.

7 So Vallejo-Campos (2013), 196.

8 Cf. Hobbs (2000), 251, and Nehamas (2004), both quoted in Sheffield (2006), 228

9 This has been brought out by Sheffield (2012), 213-215.

10 Descartes (1641), 160 .

11 Descartes (1996), Meditation 3, Section 5.

12 Psychology II (1973), ch. 6, § 3.
} 
it as good or reject it as bad. As a rule, we do not desire or avoid "blindly" but "see" because our response is based on judgment. But this judgment need not always be explicit or pronounced. We sometimes find certain people appealing or unappealing, pleasant or unpleasant "at first sight". As Shakespeare put it: "Who ever lov'd, that lov'd not at first sight?" (As You like It, Act III, Scene 5). The point is that desires are based on a certain belief.

If we put these two tripartite models of the soul together, they do not contradict each other. On the contrary, the Cartesian/Brentanonian model functions well as the foundation of the tripartite Platonic one. So we have the following "quinquepartite" model:

a) ideas, representations (phantasmata)

b) judgments

c) acts of will in the broad sense, or first-order desires corresponding to the desires of the epithymetikon

d) acts of will in a more narrow sense, or second-order desires corresponding to the desires of the thymoeides

e) acts of reason corresponding to the logistikon.

Where is eros in the Symposium located in this scheme? Surely eros is not merely something like a sexual itch, a sensation or propatheia. Eros is cognitively more advanced, an emotion or a desire (epithymia): "The main point is this: every desire (epithymia) for good things or for happiness is the "supreme and treacherous love (doleros eros) in everyone"" (Symp. 205d1-3, transl. Nehamas \& Woodruff). "Treacherous love" surely involves a cognitive component, a (perhaps erroneous) judgment on what is good (cf. Symp. 206a1, 206a1112). ${ }^{13}$ Eros in the Symposium is dependent on some cognition of the good or good-dependent. The psychology of eros in the Symposium is in this respect not different from emotions like eros in the Protagoras (cf. Prot. 352b7-8), which are not blind, but involve a cognitive component. ${ }^{14}$ Concerning the Symposium, we may say: instead of a sharp difference between the Socrates of the early dialogues and of the Symposium, we have continuity concerning the treatment of emotions like eros, since eros as a form of epithymia involves a cognitive component. The theory of Eros is not a "dividing line" between the Socrates of the early dialogues and of the Symposium. ${ }^{15}$

\section{II.}

Nevertheless Plato, the author of the Symposium, must have been aware of deviating from the Socrates of his early dialogues when he lets him report the teaching of Diotima. As the author of the Apology, Plato refers to the Pythia to give Socrates' mission divine authority (Apol. 21a6); thus, as the author of the Symposium, Plato lets Socrates refer to "a woman of Mantinea, Diotima, who was wise both in these things and in much else" (Symp. 201d2-3) to give Socrates' theory of Love the authority of a "seer". Later Diotima is called "wisest" (Symp. 208b8) and even the "most perfect sophist" (Symp. 208c1-2). She seems to have already reached the level of the philosopher-kings and queens in the Republic and may even be superior to them who are wise (cf. Resp. 546a8) by having supernatural powers (cf. Symp. 201d3-5). Although love is the only thing Socrates confesses to know (Symp. 177d7-8; cf. Theag. 128b2-4, Lysis 204c1-2), Diotima seems to realize that Socrates has not yet reached

13 These three passages have been treated in Sheffield (2006), 229-230.

14 Cf. Ferber (1991), esp. 54-55, and Rowe (2006).

$15 \mathrm{Cf}$. for the Symposium as a Socratic dialogue Rowe (2006). Pace Rowe the psychology of action is in my opinion also not the "dividing" line between the Socrates of the early dialogues and of the Republic, cf. Ferber (2013), esp. 233-236. 
the ultimate knowledge of the object of love (Symp. 209e5-210a3, transl. Rowe, small modifications by Rafael Ferber):

$\left[\mathrm{S}_{1}\right]$ Into these aspects of love, probably, Socrates, you too could be initiated (myetheies);

$\left[\mathrm{S}_{2}\right]$ but as for those aspects relating to the final revelation (ta de teleia kai epoptika), the ones for the sake of which I have taught you the rest, if one approaches these correctly - I don't know whether you would be capable of being initiated into them.

$\left[\mathrm{S}_{3}\right]$ Well, she said, I'll tell you this next part, and spare no effort in doing so;

$\left[\mathrm{S}_{4}\right]$ and you must try to follow, if you can.

The first sentence $\left[\mathrm{S}_{1}\right]$ says that Socrates could be initiated into these "aspects of love", that is, the elenctic instruction in the passage 201d1-209e3. Although Diotima here is already using the expression myeo, which means "initiate into the mysteries", she refers to the instruction she gave to Socrates by applying the Socratic method of elenchos to Socrates himself. These are the "lower" mysteries.

The second sentence $\left[\mathrm{S}_{2}\right]$ mentions ta de teleia kai epoptika, that is, the final things to be seen - terminology which remembers again that of the mysteries. ${ }^{16}$ Since with ta de teleia kai epoptika, the idea of beauty is meant, the introduction into this idea is something analogous to an introduction into the "higher" mysteries. But Diotima expresses doubt that Socrates is able to follow her. Socrates is in a similar position to Diotima as Glaukon is to Socrates in the Republic (cf. Resp. 533a1-5). As Socrates in the Republic indicates the intellectual limits of Glaucon, so Diotima mentions the limits of Socrates. Since Diotima's speech is an invention of Plato, the author of the Symposium, Plato, is indicating the intellectual limits of Socrates. The passage has been interpreted in this way by most interpreters. ${ }^{17}$

In the third sentence $\left[\mathrm{S}_{3}\right]$, Diotima behaves again toward Socrates as Socrates does toward Glaucon (Resp. 533a2), since neither spares any willingness (prothymia) to share their knowledge. So the fault is not Diotima's if Socrates cannot follow, just as it is not Socrates' fault that Glaucon cannot follow.

In the fourth sentence [ $\left.\mathrm{S}_{4}\right]$, Diotima commands Socrates to follow if he can follow, and so Diotima is reinforcing her doubt concerning the intellectual limit of her pupil. Socrates' limit is exactly indicated: the limit to pass from the agreement or the homologia he has reached with Diotima on the topic of eros to see the reality of the object of love, the idea of beauty.

Nevertheless, a minority of scholars think otherwise. I mention Alfred Edward Taylor:

It has even been seriously argued that Plato is here guilty of the arrogance of professing that he has reached philosophical heights to which the "historical" Socrates could not ascend. Everything becomes simple if we remember that the actual person speaking is Socrates, reporting the words of Diotima. Socrates [...] as a modest man, cannot say anything that would imply that he has already "attained perfection" or is assured of "final perseverance". ${ }^{18}$

It is right that Socrates is reporting Diotima. But since Plato invented this report and put it into the mouth of Socrates, the image of Socrates in the Symposium would be very different from that in the Republic. Then Socrates would have really seen, that is, understood, the idea of beauty, something he denies explicitly concerning the idea of the Good in the Republic. He says only that he would insist that "something like" (toiouton ti) "the truth itself" (auto to

${ }^{16}$ Cf. Riedweg (1987), 20-29.

${ }^{17}$ Cf. the authors mentioned in Bury (1932), 123; Sier (1997), 273 n. 225.

18 Taylor (1936), 229 n. 1. 
alethes) is finally to be seen (idein) (Resp. 533a3-5). He never says that he has seen the "truth itself". Socrates would then himself be on the level of the imagined philosopher-kings.

Of course, we find the theory of ideas already in the Euthyphron 6d-e. But what we do not find is the characterization of the ideas in the Parmenidean predicates of the Symposium: the idea of beauty (a) is always and neither comes into being nor perishes, neither increases nor decreases (210e6-211a2); (b) is absolutely beautiful (211a2-5); (c) is incorporeal (211a5$7)$; (d) is placeless $(211 \mathrm{a} 6 \mathrm{~b} 1)$; (e) is identical with itself and one (211b1); and (f) is not affected by the changing things $(211 \mathrm{~b} 3-5) .{ }^{19}$

That in the introduction of separate ideas lies the "dividing line" between Socrates and Plato is confirmed by Plato's first interpreter, Aristotle: "But Socrates did not make the universals or the definitions exist apart; his successors, however, gave them separate existence, and this was the kind of thing they called Ideas" (Metaph. M 4 1078a29-32). Aristotle is speaking of the historical Socrates. Since all other primary sources of the historical Socrates Aristophanes (Nub. $740 \mathrm{ff}$.) and Xenophon (Mem. IV 5, 11) ${ }^{20}$ - attest, like Plato in the early dialogues, that Socrates has dialectic power, we may guess that the introduction of the separate or quasi-parmenidean existence of ideas is the "dividing line" between the Socrates of the early and the middle dialogues.

In the terminology of the divided line in the Republic, we may formulate the epistemological counterpart to the introduction of separate ideas in the following way: just as the geometrical propositions express a dianoetic, but not yet a noetic knowledge (cf. Resp. 533d5), in the same vein the knowledge of Socrates is "dianoetic" knowledge of love since he gets homologoumena with Diotima, but does not have "noetic" understanding of the final object of love, namely beauty. ${ }^{21}$ This also makes sense of the following statement: "My [wisdom], I guess, will be an inferior sort of wisdom, or even a debatable one, existing as if in a dream" (Symp. 175e2-3). Socrates' wisdom is an inferior one existing like that of the mathematicians as if in a dream (Resp. 533b6-c3) because homologoumena may correspond with reality or not, as a dream may correspond with reality or not. Only "noetic" understanding of the object of love, in Diotima's or Plato's view the vision of the idea of beauty, gives correspondence.

I conclude with a guess on the philosophy of the historical Socrates: the separation of ideas and lack of (noetic) understanding of these ideas may have been the limit of the philosophy of the Socrates of the early Platonic dialogues and the historical Socrates. But since it would have been immodest if Plato, the pupil of Socrates, had overtly played the teacher of Socrates, he put his teaching into the mouth of Diotima.

Nevertheless, also this guess, based on the homologia between Aristophanes, Plato, Xenophon and Aristotle, is still "an inferior sort of wisdom, or even a debatable one, existing as in a dream" since none of us has immediate knowledge of the philosophy of the historical Socrates. ${ }^{22}$

Brentano, F., Psychology from an Empirical Standpoint, London 1973 (Transl. A. C. Rancurello, D.B. Terrelland, L. L. McAlister) = Brentano (1973).

\footnotetext{
19 This has been fully developed in the contribution of Kraus. Cf. also Ferber (1989 $)$, 38-48; Sier (1997), 11, 284.

${ }^{20}$ Cf. Philippson (1932).

${ }^{21}$ Cf. Ferber (2007).

${ }^{22}$ My thanks go to Lesley Brown, Francisco Gonzalez, Anthony Price and Nicholas Smith for some helpful remarks.
} 
Burnet, J. (ed.), Plato. Euthyphro, Apology of Socrates, Crito, ed. with notes by J. Burnet, Oxford $1924=$ Burnet (1924).

Descartes, R., Meditationes de prima philosophia, Paris $1641=$ Descartes (1641).

Descartes, R., Meditations on First Philosophy, Cambridge 1996 = Descartes (1996).

Ferber, R., Platos Idee des Guten, St. Augustin $1989^{2}(1984)=$ Ferber $\left(1989^{2}\right)$.

Ferber, R., "Sokrates: Tugend ist Wissen”, Elenchos 11 (1991) 39-66 = Ferber (1991).

Ferber, R., "What Did Socrates Know and How Did He Know It?" in M. Erler \& L. Brisson (eds.), Gorgias-Meno. Selected Papers from the Seventh Symposium Platonicum, Sankt Augustin 2007, 263-267 (enlarged German version in: Elenchos 28 [2007], 5-39) = Ferber (2007).

Ferber, R., "Ho de diokei men hapasa psyche kai toutou heneka panta prattei" in N. Notomi \& L. Brisson (eds.), Dialogues on Plato's Politeia (Republic). Selected Papers from the Ninth Symposium Platonicum. Sankt Augustin 2013, 233-241 (enlarged German version in: Elenchos 34 [2013], 5-31) = Ferber (2013).

Hobbs, A., Plato and the Hero, Cambridge $2000=$ Hobbs (2000).

Kleve, K., "Did Socrates Exist?" Grazer Beiträge 14 (1987), 123-137 = Kleve (1987)

Nehamas, A., "Only on the Contemplation of Beauty is Life Worth Living (Plato, Symposium 211d)", part of the Gray Lectures, Cambridge 2004 (unpub.), quoted in Sheffield (2006) = Nehamas (2004).

Penner, T., \& Rowe, Ch., Plato's Lysis, Cambridge 2005 = Penner \& Rowe (2005).

Philippson, R., "Sokrates' Dialektik in Aristophanes Wolken", Rheinisches Museum für Philologie 81 (1932), 30-38 = Philippson (1932).

Riedweg, Ch., Mysterienterminologie bei Platon, Philon und Klemens von Alexandrien, Berlin $1987=$ Riedweg (1987)

Rowe, Ch., "Les parties de l'âme et le désir du bien dans la République" in M. Dixsaut (avec la collaboration de F. Teisserenc) (ed.), Études sur la République de Platon. 2. De la science, du bien et des mythes, Paris 2005, 209-223 = Rowe (2005).

Rowe, Ch., "The Symposium as a Socratic Dialogue" in J. Lesher, D. Nails \& F.C.C. Sheffield (eds.), Plato's Symposium: Issues in Interpretation and Reception, Cambridge 2006, 9-22 = Rowe (2006).

Sheffield, F.C.C., "Eros Before and After Tripartition" in R. Barney, T. Brennan \& C. Brennan (eds.), Plato and the Divided Self, Cambridge $2012=$ Sheffield (2012).

Sier, K., Die Rede der Diotima. Untersuchungen zum platonischen Symposion, Stuttgart/Leipzig $1997=\operatorname{Sier}(1997)$.

Slings, S.R., Plato's Apology of Socrates. A Literary and Philosophical Study With a Running Commentary, Leiden 1994 = Slings (1994).

Sheffield, F.C.C., Plato's Symposium: The Ethics of Desire, Oxford $2006=$ Sheffield (2006).

Taylor, A.E., Plato. The Man and His Work, London \& New York 1936 = Taylor (1932).

Vallejo-Campos, A., "The Theory of Conflict in Plato's Republic" in N. Notomi \& L. Brisson (eds.), Dialogues on Plato's Politeia (Republic). Selected Papers from the Ninth Symposium Platonicum, Sankt Augustin 2013, 192-198 = Vallejo-Campos (2013). 